\title{
Glucose-specific Regulation of Aldose Reductase in Capan-1 Human Pancreatic Duct Cells In Vitro
}

\author{
Julia V. Busik, ${ }^{\star}$ Seth R. Hootman, ${ }^{\star}$ Caroline A. Greenidge, ${ }^{*}$ and Douglas N. Henry ${ }^{\star \ddagger}$ \\ $*$ Department of Physiology and ${ }^{\ddagger}$ Department of Pediatrics and Human Development, Michigan State University, East Lansing, \\ Michigan 48824
}

\begin{abstract}
Impaired pancreatic duct secretion is frequently observed in insulin-dependent diabetes mellitus (IDDM), although the cellular mechanism(s) of dysfunction remains unknown. Studies in other tissues have suggested that a hyperglycemia-induced decrease in Na,K-ATPase activity could contribute to the metabolic complications of IDDM and that increased polyol metabolism is involved in this response. The present studies examined the effects of glucose on $\mathrm{Na}, \mathrm{K}$ ATPase activity and on expression and activity of aldose reductase (AR), a primary enzyme of polyol metabolism, in Capan-1 human pancreatic duct cells. Increasing medium glucose from 5.5 to $22 \mathrm{mM}$ caused a $29 \%$ decrease in Na,KATPase activity. The decrease was corrected by $100 \mu \mathrm{M}$ sorbinil, a specific AR inhibitor. Increasing glucose from 5.5 to $110 \mathrm{mM}$ also resulted in concentration-dependent increases in AR mRNA and enzyme activity that could be resolved into two components, one that was glucose specific and observed at pathophysiological concentrations $(<55 \mathrm{mM})$ and a second that was osmotically induced at high concentrations $(>55 \mathrm{mM})$ and which was not glucose specific. The present study demonstrates that pathophysiological levels of glucose specifically activate polyol metabolism with a consequent decrease in $\mathrm{Na}, \mathrm{K}$-ATPase activity in pancreatic duct epithelial cells, and that this response to hyperglycemia could contribute to decreased pancreatic secretion observed in IDDM. This is the first report of AR regulation in the pancreatic duct epithelium. (J. Clin. Invest. 1997. 100: 1685-1692.) Key words: bicarbonate secretion • diabetes mellitus • osmotic regulation - gene regulation • polyol metabolism
\end{abstract}

\section{Introduction}

Several clinical studies (1-4) have demonstrated that fluid and bicarbonate secretion by epithelial cells of the pancreatic ex-

Portions of this work have appeared in abstract form at the American Pancreatic Association meeting, 7-8 November 1996 in Chicago, IL and at the American Diabetes Association meeting, 21-24 June 1997 in Boston, MA.

Address correspondence to Douglas N. Henry, Department of Physiology, Michigan State University, 108 Giltner Hall, East Lansing, MI 48824-1101. Phone: 517-355-6475 ext. 1278; FAX: 517-3555125; E-mail: henry@psl.msu.edu

Received for publication 26 February 1997 and accepted in revised form 14 August 1997.

J. Clin. Invest.

(C) The American Society for Clinical Investigation, Inc. 0021-9738/97/10/1685/08 \$2.00

Volume 100, Number 7, October 1997, 1685-1692

http://www.jci.org cretory duct system is impaired in $40-80 \%$ of patients with insulin-dependent diabetes mellitus (IDDM), ${ }^{1}$ although the pathogenic mechanisms through which pancreatic duct secretion is compromised in diabetes remain unknown. Studies in a variety of other end organs affected by diabetes, including peripheral nerve, retina, kidney, and vascular smooth muscle cells have demonstrated that a hyperglycemia-induced decrease in Na,K-ATPase activity could contribute to the development of diabetic complications (5-9). Na,K-ATPase exchanges intracellular $\mathrm{Na}^{+}$for extracellular $\mathrm{K}^{+}$, thereby generating the electrochemical gradients that are essential for vectorial transport of water and electrolytes across epithelia. In pancreatic duct cells, an inwardly directed $\mathrm{Na}^{+}$electrochemical gradient created by $\mathrm{Na}, \mathrm{K}-\mathrm{ATPase}$ provides the driving force for $\mathrm{H}^{+}$extrusion and $\mathrm{HCO}_{3}{ }^{-}$uptake, the essential transport steps underlying bicarbonate secretion (reviewed in references 10,11). A decrease in the activity of Na,K-ATPase in pancreatic duct cells thus could result in the diminution of bicarbonate output clinically observed in diabetic patients.

Inhibition of $\mathrm{Na}, \mathrm{K}-\mathrm{ATPase}$ activity in diabetes is believed to be linked to increased flux of glucose through the polyol metabolic pathway $(5,6,7,12)$. Aldose reductase (AR), which catalyzes the reduction of glucose to sorbitol, is a central enzyme of polyol metabolism. AR has been implicated by both clinical and basic research in the development of diabetic complications for more than a quarter of a century (13). AR inhibitors have been shown to normalize Na,K-ATPase activity in peripheral nerve (14) and to improve nerve conduction velocity and nerve repair/regeneration in diabetic rats (15). Renal tissues in diabetic rats also have been shown to have increased AR mRNA levels, immunoreactivity, and enzyme activity (16). A correlation between the development of diabetic retinopathy and expression of AR in the retinal pigment epithelium of human diabetic subjects also has been demonstrated (17).

Despite evidence for pancreatic duct dysfunction in IDDM, there is no information available on the regulation of polyol metabolism or $\mathrm{Na}, \mathrm{K}-\mathrm{ATPase}$ in pancreatic duct epithelial cells in diabetes. The present studies were therefore undertaken to analyze AR expression in the Capan-1 human pancreatic duct adenocarcinoma cell line. Transformed cell lines have been previously successfully used as in vitro models to study polyolrelated diabetic complications (18). Capan-1 cells remain well differentiated in culture (19-22) and express several essential pancreatic duct enzymes and transporters including alkaline phosphatases (19-21), carbonic anhydrase IV (21) and the cystic fibrosis transmembrane regulator (CFTR) $(19,20)$. When cultured in a three-dimensional connective tissue matrix, $\mathrm{Ca}$ pan-1 cells form polarized duct-like structures (21). Individual

1. Abbreviations used in this paper: $\mathrm{AR}$, aldose reductase; IDDM, insulin-dependent diabetes mellitus; PKC, protein kinase C; ORE, osmotic response element. 
cells exhibit apical microvilli and abundant basolateral membrane folds, hallmarks of differentiated transporting epithelial cells. The Capan-1 cell line thus provides a good in vitro pancreatic duct epithelial model with a well-preserved native phenotype. In the current studies, the effects of hyperglycemia on AR mRNA expression and enzyme activity and Na,K-ATPase activity were measured in Capan-1 cells. Results demonstrate that Capan-1 cells express AR and that it is inducible by both pathophysiological and hyperosmolar concentrations of glucose. Glucose-specific induction of AR was detected in the pathophysiological range of glucose concentrations. Inhibition of Na,K-ATPase activity by pathophysiological concentrations of glucose was also detected in Capan-1 cells. These studies support the hypothesis that pancreatic duct cells undergo a glucose-induced activation of polyol metabolism in IDDM that may lead to inhibition of $\mathrm{Na}, \mathrm{K}-\mathrm{ATPase}$ activity and, consequently, to diminution of bicarbonate output.

\section{Methods}

Reagents and supplies. RPMI-1640 culture medium, antibiotics, HBSS, and trypsin were obtained from GIBCO BRL (Gaithersburg, MD); fetal calf serum from Hyclone Labs (Logan, UT); culture dishes, and flasks from Falcon (Becton-Dickinson \& Co., Lincoln Park, NJ), and glucose, mannitol, 3-O-methylglucose (tissue culture grade) and all other commonly used chemicals and reagents from Sigma Chemical Co. (St. Louis, MO). $\alpha{ }_{-}^{32} \mathrm{P}$ dCTP was from DuPont NEN (Boston, MA).

Cell culture techniques. The present study utilized the Capan-1 human pancreatic duct adenocarcinoma cell line (HTB-79) obtained from the American Type Culture Collection (Rockville, MD). Capan-1 cells were cultured in RPMI-1640 medium supplemented with $15 \%$ fetal calf serum and $1 \%$ penicillin/streptomycin and $5.5 \mathrm{mM}$ glucose. Capan- 1 cells were passaged at a density of $40-100,000 \mathrm{cells} / \mathrm{cm}^{2}$ in $75-\mathrm{cm}^{2}$ flasks. Passaged cells were plated to yield near-confluent cultures at the end of 24-168-h experiments. 10-cm dishes were used throughout the study. The freshly plated cells were allowed to attach in standard growth medium for at least $24 \mathrm{~h}$ before incubation for various periods in different concentrations of glucose, mannitol, or 3-O-methylglucose.

$N a, K-A T P a s e$ activity. For determination of the effect of elevated glucose on Capan-1 cell Na,K-ATPase activity, cells were grown for $72 \mathrm{~h}$ in 5.5 and $22 \mathrm{mM}$ glucose until nearly confluent. Each plate of cells was rinsed twice with $5.0 \mathrm{ml}$ of HBSS, then once with $5.0 \mathrm{ml}$ of cold ATPase homogenizing medium $(250 \mathrm{mM}$ sucrose, $0.25 \mathrm{mM}$ EDTA, and $20 \mathrm{mM}$ imidazole, $\mathrm{pH}$ 7.2). The cells were then scraped from the plate in $1.0 \mathrm{ml}$ of cold homogenizing medium and transferred to a ground glass homogenizer in which they were disrupted with 15 strokes. Duplicate samples $(100 \mu \mathrm{l})$ were incubated for $20 \mathrm{~min}$ at $37^{\circ} \mathrm{C}$ in $1.4 \mathrm{ml}$ of ATPase reaction medium consisting of (in $\mathrm{mM}$ ): $5.0 \mathrm{Na}_{2} \mathrm{ATP}, 130 \mathrm{NaCl}, 20 \mathrm{KCl}, 5 \mathrm{MgCl}_{2}, 30$ imidazole ( $\mathrm{pH} 7.2$ ), \pm 0.5 ouabain. Reactions were terminated by the addition of $2.5 \mathrm{ml}$ of cold $10 \%$ trichloroacetic acid. Inorganic phosphate liberated from ATP during the reaction was determined by the procedure of Peterson (23) and normalized to homogenate protein as determined by the Coomassie blue binding assay (24). Na,K-ATPase activity was calculated as the ouabain-sensitive portion of ATP hydrolysis. Results were expressed as $\mu \mathrm{mol}$ of $\mathrm{Pi} / \mathrm{mg}$ protein per $\mathrm{h}$.

Immunoblotting of $N a, K-A T P a s e$ and $A R$. The effect of elevated glucose on Capan-1 cell Na,K-ATPase and AR protein levels were determined by quantitative immunoblotting using well-characterized antisera raised against the catalytic subunit of Na,K-ATPase (25) and human placental AR (26). 300- $\mu$ l aliquots of Capan-1 cell homogenate prepared as described for $\mathrm{Na}, \mathrm{K}$-ATPase assay were mixed with $150 \mu \mathrm{l}$ of SDS-containing sample buffer, heated at $95^{\circ} \mathrm{C}$ for $5 \mathrm{~min}$, mixed with $50 \mu \mathrm{l}$ of $20 \% \beta$-mercaptoethanol, and stored at $-20^{\circ} \mathrm{C}$. After thawing, samples corresponding to $10 \mu \mathrm{g}$ of cell protein per lane were electrophoresed on $7.5 \%$ linear polyacrylamide mini-gels. The separated proteins were then transferred to nitrocellulose sheets by conventional procedures (27). The transferred Na,K-ATPase catalytic subunit or AR protein was visualized by incubation for $2 \mathrm{~h}$ at $23^{\circ} \mathrm{C}$ in PBS containing a 1:400 dilution of the primary anti-Na, KATPase or anti-AR antibody, followed by a 90 -min incubation at $23^{\circ} \mathrm{C}$ in PBS containing a 1:400 dilution of a commercial immunoglobulin-peroxidase conjugate (Sigma Chemical Co.). After development for peroxidase reactivity, blots were quantitated by scanning densitometry using a high resolution AGFA ${ }^{\circledR}$ optical scanner and National Institutes of Health (NIH) Image software.

AR mRNA expression. AR mRNA levels were measured by Northern and dot blot analysis. Total RNA from Capan-1 cells grown in $5.5,11,22,33,55,77$, and $110 \mathrm{mM}$ glucose for $0-168 \mathrm{~h}$ was obtained by a modification of the acid-phenol extraction method and $10 \mu \mathrm{g}$ of RNA were resolved on denaturing $2.2 \mathrm{M}$ formaldehyde- $1 \%$ agarose gels (28). After electrophoresis, RNA was transferred to ZetaBind ${ }^{\circledR}$ nylon filters (CUNO, Inc., Meriden, CT) by capillary blotting. Filters were stained with methylene blue to examine the integrity of the RNA and to assess the uniformity of loading and transfer. Dot blot analysis was performed with serial dilutions of RNA applied to ZetaBind $^{\circledR}$ nylon filters using a vacuum manifold. The filters were fixed and hybridized at high stringency (29). Human retinal AR cDNA consisting of exons 2 to 6 was used for making AR probes (28). Chicken $\beta$-actin cDNA (30) was used for making $\beta$-actin probes. The probes were labeled with ${ }^{32} \mathrm{P}$-dCTP using random primers to a specific activity of $10^{9} \mathrm{dpm} / \mathrm{mg}$ and separated from unincorporated nucleotides by gel filtration. After $18 \mathrm{~h}$, hybridized filters were washed at high stringency (29). Autoradiograms were obtained with multiple exposures to remain within the linear range of the film and were quantitated by scanning densitometry using a high resolution AGFA ${ }^{\circledR}$ optical scanner and NIH Image software. Each blot was serially hybridized with both AR and $\beta$-actin. Filters were stripped until free of radioactivity before rehybridization.

AR activity. AR activity was assessed spectrophotometrically (31) at $30^{\circ} \mathrm{C}$ by monitoring the decrease in absorbance of NADPH at 340 $\mathrm{nm}$ for $10 \mathrm{~min}$ in the absence and presence of $10 \mathrm{mM}$ glyceraldehyde as a substrate. Enzyme activity was normalized to supernatant protein content and expressed as nmol NADPH oxidized/mg protein per min. Supernatant protein content was measured using the bicinchoninic acid (BCA) protein assay reagent (Pierce, Rockford, IL).

Statistical analysis. Results are expressed as means \pm SE of at least four experiments. Statistical significance of differences between experimental groups was determined using Student's $t$ tests.

\section{Results}

Glucose-induced decrease in Na,K-ATPase activity in Capan-1 cells. ATPase activities, both ouabain sensitive (Na,K-ATPase) and ouabain insensitive (Mg-ATPase), were determined in Capan-1 cells cultured in normal $(5.5 \mathrm{mM})$ and pathophysiological $(22 \mathrm{mM})$ concentrations of glucose for $72 \mathrm{~h}$. A statistically significant $(P<0.01)$ decrease in Na,K-ATPase activity was seen in $22 \mathrm{mM}$ glucose (Fig. $1 A$ ). That this effect was selective for $\mathrm{Na}, \mathrm{K}$-ATPase is indicated by the observation that ouabain-insensitive Mg-ATPase activity was not significantly altered by incubation in $22 \mathrm{mM}$ glucose (Fig. $1 B$ ).

It has been shown in nerve, renal, and retinal tissue that hyperglycemia-induced inhibition of $\mathrm{Na}, \mathrm{K}$-ATPase activity is due to increased flux of glucose through the polyol metabolic pathway (5-7). To test whether a similar mechanism is involved in the observed inhibition of Na,K-ATPase in Capan-1 cells, we attempted to reverse the inhibition of Na,K-ATPase with sorbinil, a specific inhibitor of AR. All sorbinil experiments were carried out in serum- and antibiotic-free medium to prevent binding and inactivation of sorbinil by serum pro- 
A

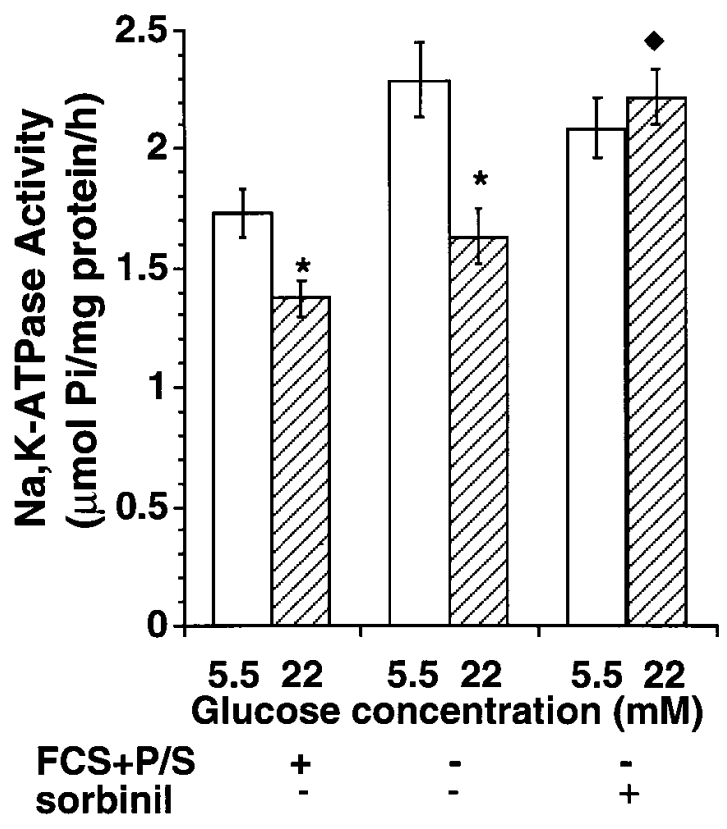

B



Figure 1. Effect of increased glucose on ATPase activity in Capan-1 cells. Na,K-ATPase $(A)$ and $\mathrm{Mg}$-ATPase $(B)$ activities were measured in Capan-1 cells cultured in normal ( $5.5 \mathrm{mM}$, open bars) and in pathophysiological (22 $\mathrm{mM}$, hatched bars) concentrations of glucose for $72 \mathrm{~h}$ in media containing $15 \%$ FCS and penicillin/streptomycin $(P / S)$, in media without serum and antibiotics and in media without serum and antibiotics containing $100 \mu \mathrm{M}$ sorbinil as indicated. $* P<$ 0.01 compared to value in $5.5 \mathrm{mM}$ glucose. ${ }^{\bullet} P<0.01$ compared to value in $22 \mathrm{mM}$ glucose without sorbinil. Results represent means \pm SE of five to eight experiments.

teins. To make sure that serum- and antibiotic-free medium does not affect Na,K-ATPase activity, an additional control experiment was performed. The cells were incubated in serumand antibiotic-free media containing 5.5 or $22 \mathrm{mM}$ glucose with or without $100 \mathrm{mM}$ sorbinil for $72 \mathrm{~h}$, at which time $\mathrm{Na}, \mathrm{K}$ -
ATPase and Mg-ATPase activities were determined. Addition of $100 \mu \mathrm{M}$ sorbinil completely reversed the decrease in $\mathrm{Na}, \mathrm{K}$ ATPase activity induced by $22 \mathrm{mM}$ glucose (Fig. $1 A$ ).

To determine whether the change in $\mathrm{Na}, \mathrm{K}-\mathrm{ATPase}$ activity observed was due to changes in enzyme expression, changes in the kinetic properties of the enzyme, or both, the levels of Capan-1 Na,K-ATPase protein were assessed by quantitative immunoblotting. The primary antibody reacted with a single protein of approximately 97,000 mol. wt. in Capan-1 cells cultured in both 5.5 and $22 \mathrm{mM}$ glucose (Fig. $2 \mathrm{~A}$ ). Densitometric analysis of blots from four preparations of Capan-1 cells cultured in each of the two concentrations showed no significant differ-

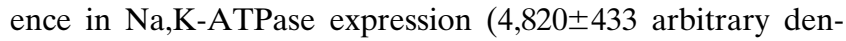
sitomentry units at $5.5 \mathrm{mM}$ vs. 5,010 $\pm 564 \mathrm{U}$ at $22 \mathrm{mM}$; mean \pm SE, Fig. $2 B$ ). These results indicate that the observed decrease in activity is due to changes in the kinetic properties of the enzyme rather than to a decrease in enzyme abundance.

Effect of glucose on AR mRNA expression in Capan-1 cells. As noted above, AR is a key enzyme of polyol metabolism, and has been implicated in the development of diabetic complications in retinal, renal, nerve, and vascular smooth muscle tissue. It is not known whether pancreatic duct cells express AR and, if so, whether expression of the enzyme is al-

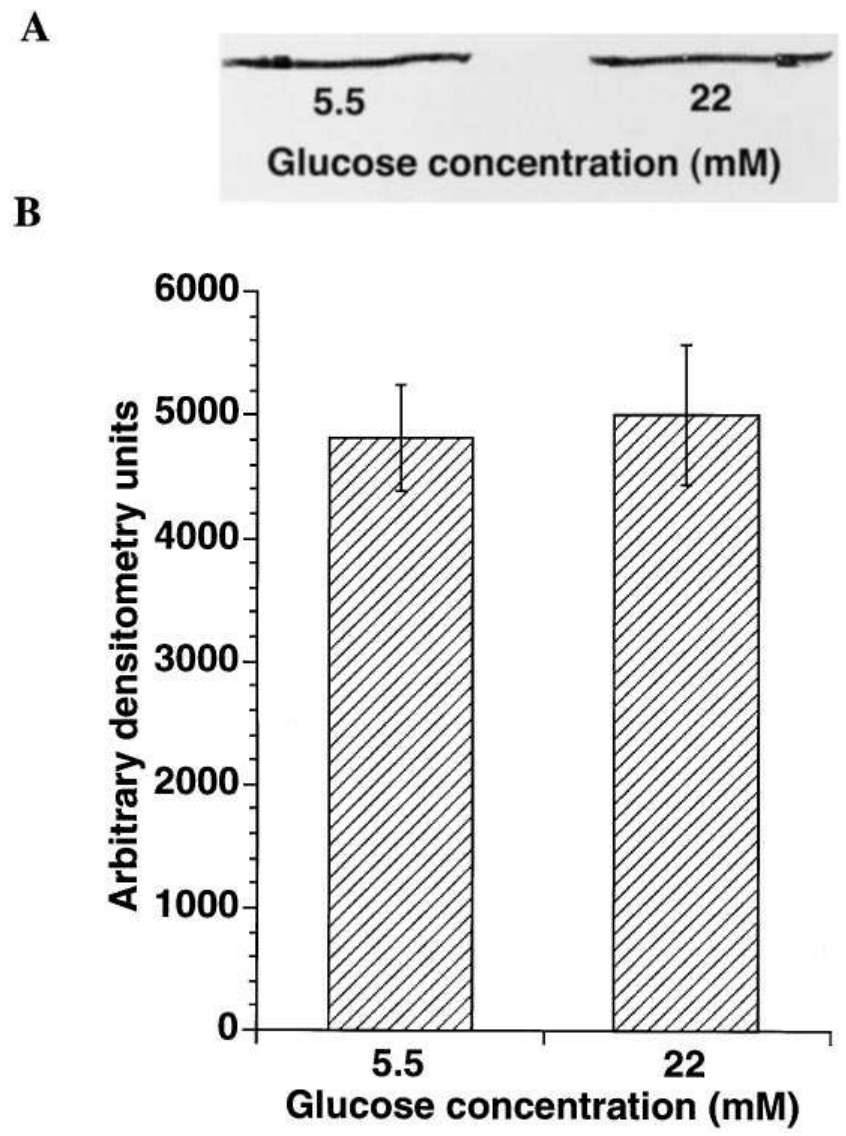

Figure 2. $\mathrm{Na}, \mathrm{K}-\mathrm{ATPase}$ protein expression in Capan-1 cells cultured in different glucose concentrations. $(A)$ Immunoblots of Na,K-ATPase protein from Capan-1 cells cultured in normal $(5.5 \mathrm{mM})$ and in pathophysiological $(22 \mathrm{mM})$ concentrations of glucose for $72 \mathrm{~h} .(B)$ Quantitation of Na,K-ATPase protein expression from immunoblots. Results represent means \pm SE of density determinations from four immunoblots in each group. 
$\mathbf{A}$
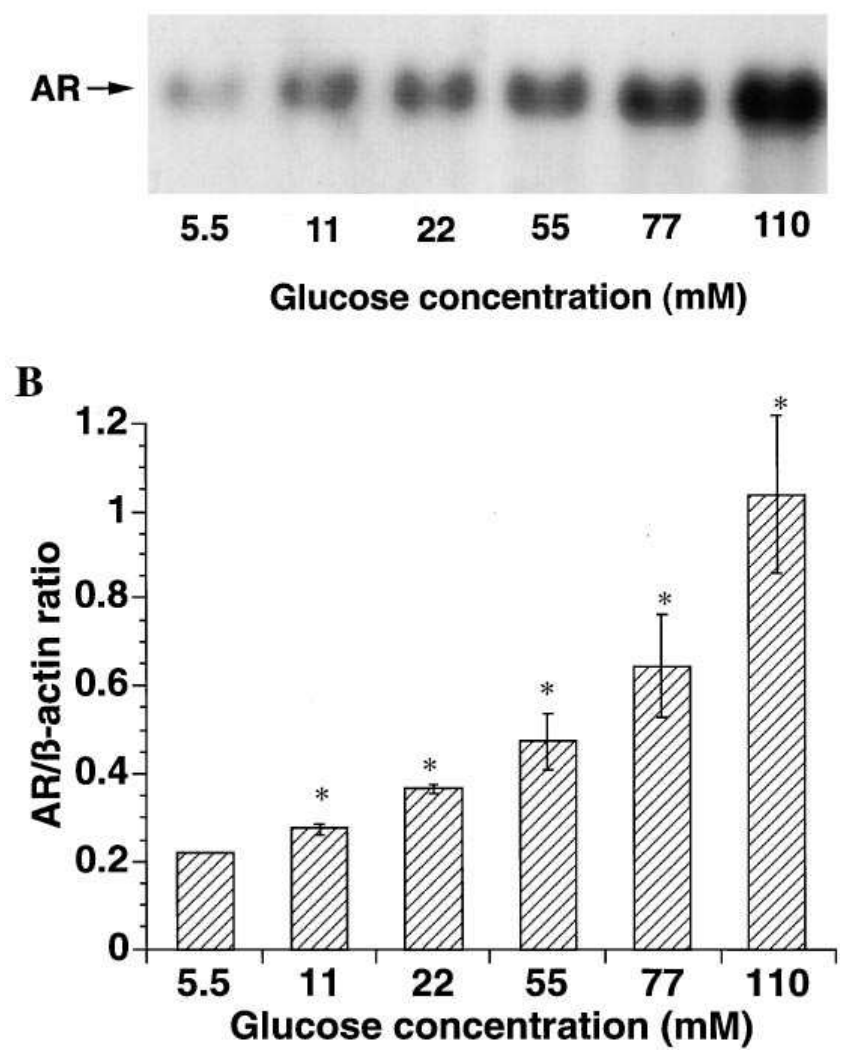

Figure 3. Induction of AR mRNA by glucose in Capan-1 cells. $(A)$ Northern blot analysis of AR mRNA expression in Capan-1 cells cultured in 5.5-110 mM glucose for $24 \mathrm{~h}$. AR cDNA hybridized to a single band of an appropriate size $(\sim 1.8 \mathrm{~kb})$ for the AR mRNA transcript. (B) Dot blot quantitation of AR mRNA expression in Capan- 1 cells cultured in $5.5-110 \mathrm{mM}$ glucose for $24 \mathrm{~h}$. The data were normalized to $\beta$-actin mRNA expression. ${ }^{*} P<0.05$ in $11-110 \mathrm{mM}$ glucose vs. $5.5 \mathrm{mM}$ glucose. Results represent means $\pm \mathrm{SE}$ of four experiments.

tered by glucose. To address these questions, AR mRNA expression in Capan-1 cells exposed for $24 \mathrm{~h}$ to glucose concentrations ranging from 5.5 to $110 \mathrm{mM}$ was determined. Northern blot analysis demonstrated that AR cDNA hybridized to a single band of the appropriate size $(\sim 1.8 \mathrm{~kb})$ for the AR mRNA transcript (Fig. $3 A$ ). Expression of Capan-1 cell $\beta$-actin was not affected by increasing medium glucose up to $110 \mathrm{mM}$ (data not shown). Dot blot quantitation of AR mRNA expression was therefore normalized to $\beta$-actin as shown in Fig. 3 B. Increasing glucose in the culture medium from 5.5 to $110 \mathrm{mM}$ caused a concentration-dependent increase in AR mRNA expression. The increase in AR mRNA expression was significant at and $>11 \mathrm{mM}$ glucose relative to $5.5 \mathrm{mM}$ glucose.

Time course of AR mRNA induction in Capan-1 cells. The time dependence of AR mRNA induction was determined in Capan-1 cells exposed to $110 \mathrm{mM}$ glucose, a concentration that caused nearly maximal induction of AR mRNA in doseresponse experiments. The increase in AR mRNA level was first detected after $8 \mathrm{~h}$ of exposure to $110 \mathrm{mM}$ glucose and
A


Figure 4. Time course of AR mRNA induction by glucose in Capan-1 cells. $(A)$ Northern blot analysis of the time course of AR mRNA induction by $110 \mathrm{mM}$ glucose in Capan-1 cells. (B) Dot blot quantitation of the time course of AR mRNA induction by $110 \mathrm{mM}$ glucose in Capan- 1 cells. The data were normalized to $\beta$-actin mRNA expression. $* P<0.05$ in $12-168 \mathrm{~h}$ vs. $0 \mathrm{~h}$. Results represent means \pm SE of four experiments.

reached a maximal steady-state level after $24 \mathrm{~h}$, which was maintained for up to $168 \mathrm{~h}$ (Fig. $4, A$ and $B$ ).

Effect of glucose on AR protein expression and enzyme activity. To further elucidate the effect of glucose on activation

A

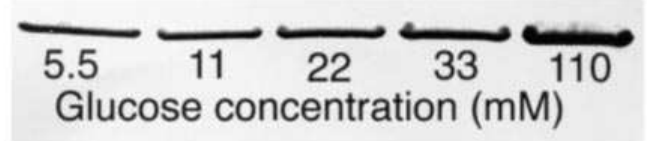

B

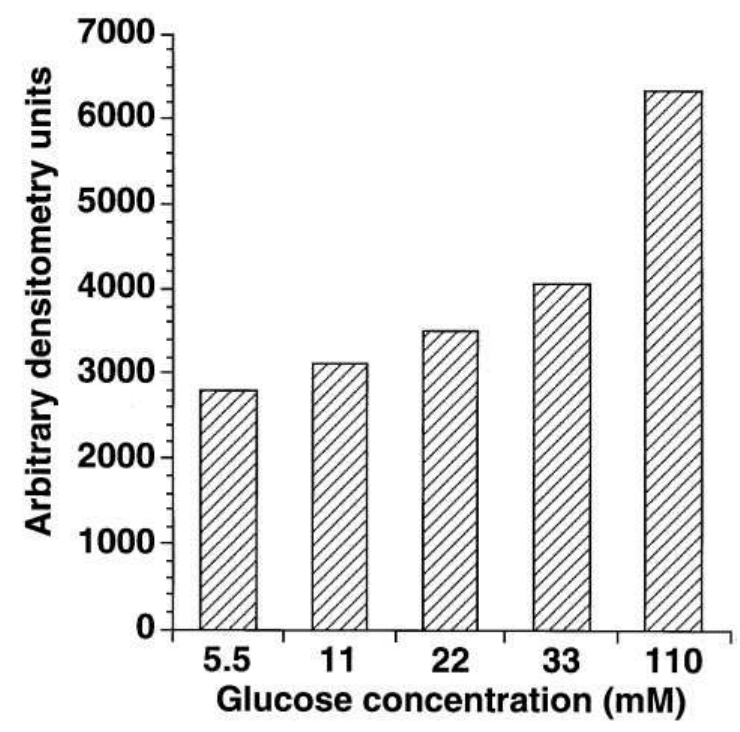

Figure 5. Effect of glucose on AR protein expression in Capan-1 cells. $(A)$ Immunoblots of AR protein from Capan-1 cells cultured in 5.5-110 mM glucose for $72 \mathrm{~h}$. The AR protein appeared as a single band of $\sim 40,000 \mathrm{~mol}$ wt. (B) Quantitation of AR protein expression from immunoblot shown in Fig. 5 A. 


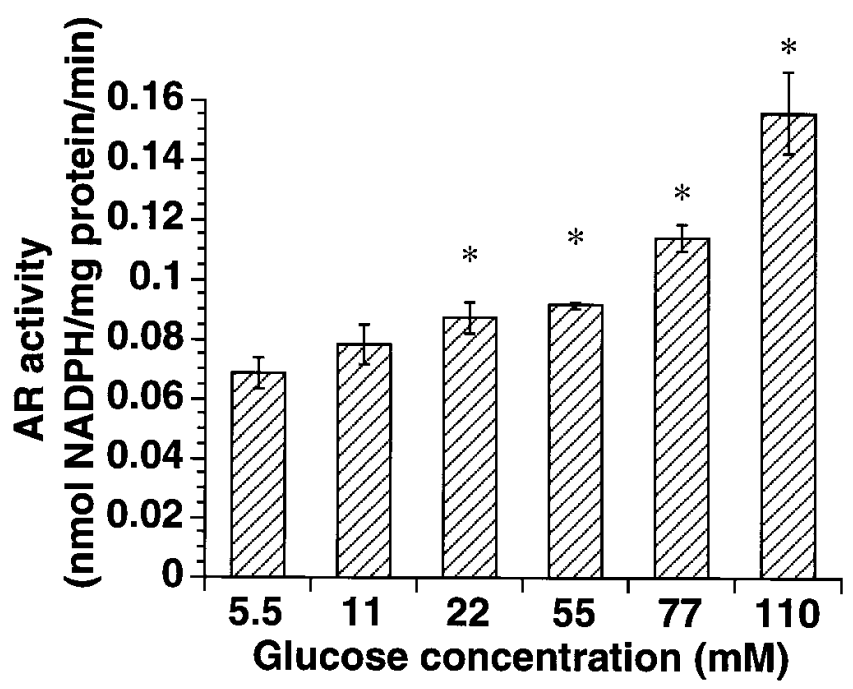

Figure 6. Effect of glucose on AR enzyme activity in Capan-1 cells. AR enzyme activity was measured in Capan-1 cells exposed to 5.5$110 \mathrm{mM}$ glucose for $72 \mathrm{~h} . * P<0.05$ in $22-110 \mathrm{mM}$ vs. $5.5 \mathrm{mM}$ glucose. Results represent means \pm SE of 10 experiments.

of polyol metabolism in Capan-1 cells, we determined whether the observed AR mRNA induction by glucose was accompanied by an increase in AR protein expression and enzyme activity. Both AR protein expression (Fig. 5) and enzyme activ-



Figure 7. Time dependence of the effect of glucose on AR enzyme activity in Capan-1 cells. AR enzyme activity was measured in Capan-1 cells exposed to $110 \mathrm{mM}$ glucose for $0-72 \mathrm{~h}$. $* P<0.05$ in $24-72 \mathrm{~h}$ vs. $0 \mathrm{~h},{ }^{\bullet} P<0.05$ in $48-72 \mathrm{~h}$ vs. $24 \mathrm{~h}$. Results represent means \pm SE of six experiments. ity (Fig. 6) in Capan-1 cells cultured in 5.5-110 mM glucose for $72 \mathrm{~h}$ were increased in parallel after AR mRNA induction. An increase in AR enzyme activity was first detected after $24 \mathrm{~h}$ of exposure to $110 \mathrm{mM}$ glucose and reached a maximal level after $48 \mathrm{~h}$ (Fig. 7). Thus, the $110 \mathrm{mM}$ glucose-induced increase in AR mRNA expression was followed within $24 \mathrm{~h}$ by an increase in AR enzyme activity in Capan-1 cells.

Substrate specificity of AR $m R N A$ induction. To determine whether the observed increase in AR mRNA expression and enzyme activity was caused by an increase in glucose metabolism, glucose transport, or by osmotic stress, Capan-1 cells were exposed to mannitol, an osmotically active hexose sugar that does not undergo facilitated transport, and to 3-O-methylglucose, a transportable, but nonmetabolizable glucose analog. In contrast to glucose, neither $22 \mathrm{mM}$ mannitol nor $22 \mathrm{mM}$ 3- $O$-methylglucose induced AR mRNA expression (Fig. $8 \mathrm{~A}$ ) or enzyme activity (Fig. $8 B$ ). Moreover, inhibition of AR mRNA

$\mathbf{A}$

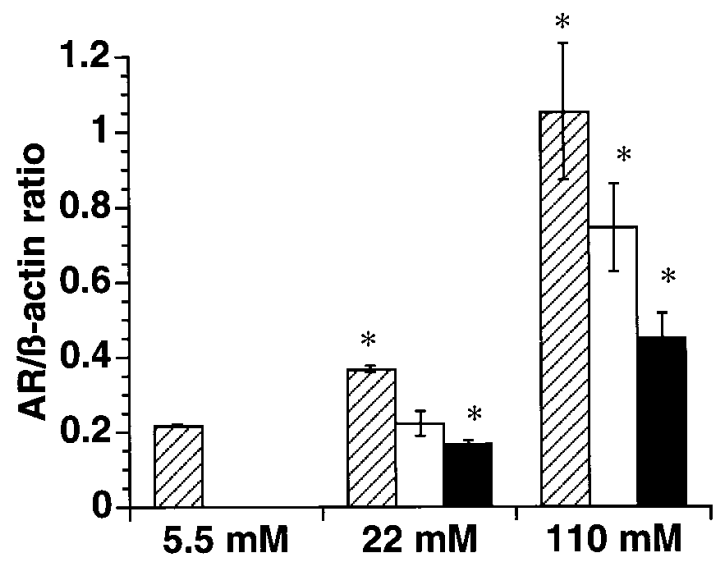

B

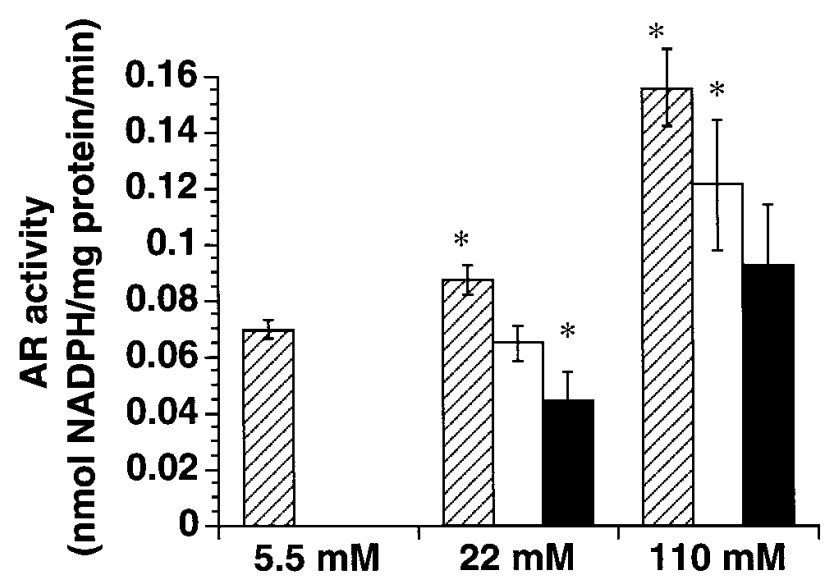

Figure 8. Glucose-specific induction of AR mRNA and enzyme activity in Capan-1 cells. $(A)$ Dot blot quantitation of AR mRNA expression in Capan-1 cells exposed to pathophysiological $(22 \mathrm{mM})$ or hyperosmolar $(110 \mathrm{mM})$ concentrations of glucose (hatched bar), mannitol (open bar), and 3-O-methylglucose (black bar). $* P<0.05$ compared to control (5.5 mM glucose) value. Results represent means $\pm \mathrm{SE}$ of four experiments. (B) AR enzyme activity in Capan-1 cells cultured as in Fig. $A . * P<0.05$ compared to control (5.5 $\mathrm{mM}$ glucose) value. Results represent means $\pm \mathrm{SE}$ of eight experiments. 
expression and enzyme activity was detected when cells were exposed to $22 \mathrm{mM} 3-O$-methylglucose compared to the control levels of glucose $(5.5 \mathrm{mM})$. When concentrations of mannitol and 3-O-methylglucose were increased to $110 \mathrm{mM}$, each caused AR mRNA induction (Fig. $8 A$ ) and an increase in enzyme activity (Fig. $8 B$ ). However, the degree of AR induction was substantially lower in $110 \mathrm{mM}$ mannitol than in $110 \mathrm{mM}$ glucose and even lower in $110 \mathrm{mM} 3-O$-methylglucose.

\section{Discussion}

The present study used the human pancreatic duct adenocarcinoma cell line, Capan-1, as an in vitro model to analyze the effects of hyperglycemia on the pancreatic duct system. Capan-1 cells represent a well differentiated cell line of ductal origin (19-22). In the present study we have shown that Capan-1 cells also express Na,K-ATPase and AR, and that the activities of both enzymes can be altered by hyperglycemia.

An increase in medium glucose concentration in the pathophysiological range significantly inhibited $\mathrm{Na}, \mathrm{K}$-ATPase activity in Capan-1 cells. In pancreatic duct cells, the $\mathrm{Na}^{+}$electrochemical gradient created by $\mathrm{Na}, \mathrm{K}-\mathrm{ATPase}$ drives $\mathrm{H}^{+}$extrusion and $\mathrm{HCO}_{3}{ }^{-}$uptake, the important steps for vectorial bicarbonate secretion $(10,11)$. A hyperglycemia-induced reduction in $\mathrm{Na}, \mathrm{K}-\mathrm{ATPase}$ activity of the magnitude observed in the current studies might, therefore, result in a decreased ability of the pancreatic duct system to secrete fluid and bicarbonate. Whether a comparable decrease in enzyme activity occurs in the pancreatic ducts of patients with IDDM is unknown, although the possibility is supported by recent studies in our laboratory which demonstrated that $\mathrm{Na}, \mathrm{K}$-ATPase activity was decreased $76 \%$ in pancreatic ducts isolated from guinea pigs with streptozotocin-induced diabetes (32).

There has been no information available on the pathogenic mechanisms through which glucose may cause inhibition of $\mathrm{Na}, \mathrm{K}-\mathrm{ATPase}$ activity in pancreatic duct cells, although studies on other tissues have demonstrated that hyperglycemia-induced inhibition of $\mathrm{Na}, \mathrm{K}-\mathrm{ATPase}$ activity in diabetes is linked to increased AR-mediated flux of glucose through the polyol metabolic pathway $(5-7,12)$. In the present study, we demonstrated for the first time that pancreatic duct cells express AR and that it is inducible by both pathophysiological and hyperosmolar concentrations of glucose. AR mRNA and protein expression as well as AR enzyme activity were increased by glucose in $\mathrm{Ca}-$ pan-1 cells. Moreover, sorbinil, a specific inhibitor of AR, reversed the decrease in Na,K-ATPase induced by $22 \mathrm{mM}$ glucose. These data directly demonstrate that glucose-induced activation of AR leads to inhibition of $\mathrm{Na}, \mathrm{K}-\mathrm{ATPase}$ in $\mathrm{Ca}-$ pan-1 cells.

The regulation of $\mathrm{AR}$ has been best described in renal medullary tissue, which faces extracellular hyperosmolarity during urinary concentration (33-37). AR in renal medullary cells works as a part of a physiological osmoregulatory mechanism to adjust intracellular osmolarity by accumulation of the nonionic, organic intracellular osmolyte sorbitol. The mechanism through which extracellular osmolarity in the renal medulla regulates AR activity was recently shown to involve activation of an osmotic response element (ORE) of the AR gene, an 11-bp nucleotide sequence located $3.7 \mathrm{~kb}$ upstream from the transcription initiation site that mediates hypertonicityresponsive enhancer activity (38). It is not known whether the same mechanism is involved in AR regulation in end organs affected by diabetes. Levels of glucose sufficient to substantially raise serum osmolarity are not sustained in diabetes. Thus, high osmolarity probably does not account for the activation of AR outside of the renal medulla. In the present study, AR was specifically induced by pathophysiological concentrations of glucose. Mannitol, an osmotically active hexose sugar that does not undergo facilitated transport, and 3-Omethylglucose, a transportable, but nonmetabolizable glucose analog, were not effective inducers of AR in the pathophysiological range of concentrations. In addition, inhibition of $\mathrm{AR}$ mRNA expression and enzyme activity was detected in Capan-1 cells exposed to pathophysiological concentrations of 3-O-methylglucose. These results may be explained if $3-O$-methylglucose competes with glucose for a common membrane transporter. In this case, an increase in 3-O-methylglucose concentration would lead to decreased glucose uptake and metabolism and consequently to a reduction of AR activity. These results suggest that nonosmotic, glucose-specific, induction of AR occurs in pancreatic duct cells exposed to pathophysiological concentrations of glucose. The mechanism of nonosmotic, glucose-specific, induction of AR remains unknown. Osmotic regulation of AR is also preserved in pancreatic duct cells, as mannitol and 3-O-methylglucose were effective inducers of $\mathrm{AR}$ at hyperosmolar concentrations.

The mechanism(s) through which an increase in AR activity may lead to inhibition of $\mathrm{Na}, \mathrm{K}$-ATPase activity in pancreatic duct cells is unknown. AR catalyzes the reduction of glucose to sorbitol, the accumulation of which has been postulated to alter the metabolism of myo-inositol, a six carbon cyclic polyol, in peripheral nerve, retina, and renal tissues $(28,39,40)$. It has been demonstrated in nerve and retina that depletion of myoinositol may reduce its incorporation into cellular phosphoinositide pools, resulting in tissue-specific changes in diacylglycerol (DAG), the chief physiological activator of protein kinase C (PKC) $(39,41)$. Increased oxidation of sorbitol to fructose also has been shown to alter cellular redox potential, resulting in an increase in the cytosolic ratio of NADH/NAD ${ }^{+}$ in glomerular mesangial cells and microvasculature $(42,43)$. This change in redox potential can impact many cellular processes but, in particular, may cause increased de novo synthesis of DAG (43) leading to elevation of PKC activity.

That alterations in PKC activity may play a central role in diabetic complications is indicated by the observation by Ishii and coworkers (44) that vascular dysfunctions in diabetic rats could be ameliorated by oral administration of LY333531, a specific inhibitor of the $\beta-2$ isoform of PKC, and by studies of $\mathrm{Na}, \mathrm{K}-\mathrm{ATPa}$ e levels in sciatic nerves of diabetic mice by Hermenegildo (45), which demonstrated that recovery of depressed $\mathrm{Na}, \mathrm{K}$-ATPase activity could be induced by administration of the PKC inhibitors, $\mathrm{H} 7$ and calphostin $\mathrm{C}$. These studies suggest that PKC may be directly involved as a mediator of the decrease in Na,K-ATPase activity. This assumption is supported by the observations that $\mathrm{PKC}$ can phosphorylate the catalytic subunit of purified $\mathrm{Na}, \mathrm{K}-\mathrm{ATPase}(46)$ and that this phosphorylation inhibits the activity of the enzyme by as much as 50\% (47). Middleton and coworkers (48) also have reported that phorbol ester activation of PKC in intact kidney epithelial cells inhibited $\mathrm{Na}, \mathrm{K}-\mathrm{ATPase}$ activity by $42 \%$ and phorbol esters have been reported to increase ${ }^{32} \mathrm{P}$ labeling of the catalytic subunit of Na,K-ATPase in sciatic nerves (49).

$\mathrm{Xia}$ and coworkers have recently demonstrated glucoseinduced sequential activation of PKC and cytoplasmic phos- 
pholipase A2 (cPLA2), as well as increased release of AA and its metabolites and decreased $\mathrm{Na}, \mathrm{K}$-ATPase activity in cultured vascular smooth muscle cells (50). The increase in cPLA2 activity could be prevented by the PKC inhibitor, GFX, while AACOCF, a cPLA2 inhibitor, prevented the glucose-induced decrease in Na,K-ATPase activity. The authors concluded that hyperglycemia causes a chronic increase in PKC activity which activates cPLA2 by direct phosphorylation and that Na,K-ATPase activity is suppressed not by inhibitory phosphorylation of the enzyme by PKC, but by increased liberation of AA and its metabolites.

Hyperglycemia-induced activation of $\mathrm{AR}$ thus may result in chronic hyperstimulation of PKC, which may cause a decrease in $\mathrm{Na}, \mathrm{K}$-ATPase activity either by direct phosphorylation or through AA production. A reduction in the activity of this key transport protein could account for the decrease in pancreatic bicarbonate output clinically observed in diabetic patients. Results of the current studies support the hypothesis that hyperglycemia-induced activation of polyol metabolism may play a central role in the development of diabetic complications in pancreatic duct cells.

\section{Acknowledgments}

The anti-Na,K-ATPase antibody utilized in these studies was provided by Stephen A. Ernst, Ph.D., Department of Anatomy and Cell Biology, University of Michigan, Ann Arbor, MI. The anti-AR antibody was a generous gift from Peter F. Kador, Ph.D., Laboratory of Ocular Therapeutics, National Eye Institute, NIH, Bethesda, MD. Sorbinil was provided by Peter J. Oates, Ph.D., Central Research Division, Pfizer Inc. (Groton, CT).

This work was supported by National Institutes of Health (NIH) grant R01 DK46607 to S.R. Hootman and National Institutes of Health grant K11 DK02193, Juvenile Diabetes Foundation International Research Grant No. 195044 and GCRC grant M01-RR00042 to D.N. Henry.

\section{References}

1. Chey, W.Y., H. Shay, and C.R. Shuman. 1963. External pancreatic secretion in diabetes mellitus. Ann. Intern. Med. 59:812-821.

2. Domschke, W., F. Tympner, S. Domschke, and L. Demling. 1975. Exocrine function in juvenile diabetics. Dig. Dis. 20:309-312.

3. Freer, B.M., J.H.B. Saunders, K.G. Wormsley, and I.A.D. Boucher. 1976. Exocrine pancreatic function in juvenile-onset diabetes mellitus. Gut. 17:685691.

4. Frier, B.M., O.K. Faber, C. Binder, and H.L. Eliott. 1978. The effect of residual insulin secretion on exocrine pancreatic function in juvenile-onset diabetes mellitus. Diabetologia. 14:301-304.

5. Greene, D.A., and S.A. Lattimer. 1983. Impaired rat sciatic nerve sodium-potassium adenosine triphosphatase in acute streptozotocin diabetes and its correction by dietary myo-inositol supplementation. J. Clin. Invest. 72:10581063.

6. Cohen, M.P., A. Dasmahapatra, and E. Shapiro. 1985. Reduced glomerular sodium/potassium adenosine triphosphatase activity in acute streptozotocin diabetes and its prevention by oral sorbinil. Diabetes. 34:1071-1074.

7. MacGregor, L.C., and F.M. Matschinsky. 1986. Experimental diabetes impairs function of the retinal pigmented epithelium. Metab. Clin. Exp. 35 (Suppl. 1):28-34.

8. Nishida, K., T. Ohara, J. Johnson, J.S. Wallner, J. Wilk, N. Sherman, K. Kawakami, K. Sussman, and B. Draznin. 1992. Na/K-ATPase activity and its $\alpha \mathrm{II}$ subunit gene expression in rat skeletal muscle: influence of diabetes, fasting, and refeeding. Metab. Clin. Exp. 41:56-62.

9. Simmons, D.A., and A.I. Winegrad. 1989. Mechanism of glucose-induced $\left(\mathrm{Na}^{+}, \mathrm{K}^{+}\right)$-ATPase inhibition in aortic wall of rabbits. Diabetologia. 32:402-408.

10. Hootman, S.R., and J. de Ondarza. 1993. Overview of pancreatic duct physiology and pathophysiology. Digestion. 54:323-330.

11. Case, R.M., and B.E. Argent. 1993. Pancreatic duct cell secretion: control and mechanisms of transport. In The Pancreas: Biology, Pathobiology, and Disease. 2nd ed. V.L.W. Go, E.P. DiMagno, J.D. Gardner, E. Lebenthal, H.A. Reber, and G.A. Scheele, editors. Raven Press, New York. 301-350.
12. Porte, D., Jr., and M.W. Schwartz. 1996. Diabetes complications: Why is glucose potentially toxic? Science (Wash. DC). 272:699-700.

13. Kinoshita, J.H. 1965. Pathways of glucose metabolism in the lens. Invest. Ophthalmol. \& Visual Sci. 4:619-628.

14. Kim, J., H. Kyriazi, and D.A. Greene. 1991. Normalization of $\mathrm{Na}^{+}-\mathrm{K}^{+}-$ ATPase activity in isolated membrane fraction from sciatic nerves of streptozotocin-induced diabetes rats by dietary myo-inositol supplementation in vivo or protein kinase C agonists in vitro. Diabetes. 40:558-567.

15. Sima, A.A.F., A Prashar, W.X. Zhang, S. Chakragarti, and D.A Greene. 1990. Preventative effect of long term aldose reductase inhibition (Ponalrestat) on nerve conduction and sural nerve structure in the spontaneously diabetic BB-rat. J. Clin. Invest. 85:1410-1420.

16. Ghahary, A., J. Luo, Y. Gong, S. Chakrabarti, A.A.F. Sima, and L.J. Murphy. 1988. Increased renal aldose reductase activity, immunoreactivity, and mRNA in streptozotocin-induced diabetic rats. Diabetes 38:1067-1071.

17. Vinores, S.A., P.A. Campochiaro, E.H. Williams, E.E. May, R. Green, and R.L. Sorenson. 1988. Aldose reductase expression in human diabetic retina and retinal pigment epithelium. Diabetes 37:1658-1664.

18. Shindo, H., T.P. Thomas, D.D. Larkin, A.K. Karihaloo, H. Inada, T. Onaya, M.J. Stevens, and D.A. Greene. 1996. Modulation of basal nitric oxidedependent cyclic-GMP production by ambient glucose, myo-inositol, and protein kinase C in SH-SY5Y human neuroblastoma cells. J. Clin. Invest. 97:736745 .

19. Becq, F., M. Fanjul, M. Merten, C. Figarella, E. Hollande, and M. Gola. 1993. Possible regulation of CFTR-chloride channels by membrane-bound phosphatases in pancreatic duct cells. FEBS Lett. 327:337-342.

20. Becq, F., E. Hollande, and M. Gola. 1993. Phosphorylation-regulated low-conductance $\mathrm{Cl}^{-}$channels in a human pancreatic duct cell line. Pflugers Arch. 425:1-8.

21. Fanjul, M., and E. Hollande. 1993. Morphogenesis of "duct-like" structures in three-dimensional cultures of human cancerous pancreatic duct cells (Capan-1). In Vitro Cell. \& Dev. Biol. 29A:574-584.

22. Becq, F, M. Fanjul, and I. Mahieu. 1992. Anion channels in a human pancreatic cancer cell line (Capan-1) of ductal origin. Pflugers Arch. 420:46-53.

23. Peterson, G.L. 1978. Simplified analysis of inorganic phosphate in solutions. Anal. Biochem. 84:164-172.

24. Bradford, M.M. 1976. A rapid and sensitive method for the quantitation of microgram quantities of protein utilizing the principle of protein-dye binding. Anal. Biochem. 72:248-254.

25. Hieber, V., G.J. Siegal, T. Desmond, J. Lee-Hwa Liu, and S.A. Ernst. 1989. Na,K-ATPase: comparison of the cellular localization of $\alpha$-subunit mRNA and polypeptide in mouse cerebellum, retina, and kidney. J. Neurosci. Res. 23:9-20.

26. Kador, P.F., D. Carper, and J.H. Kinoshita. 1981. Rapid purification of human placental aldose reductase. Anal. Biochem. 114:53-58.

27. Towbin, H., T. Staehelin, and J. Gordon. 1979. Electrophoretic transfer of proteins from polyacrylamide gels to nitrocellulose sheets: procedure and some applications. Proc. Natl. Acad. Sci. USA. 76:4350-4354.

28. Henry, D.N., M. Del Monte, D.A. Greene, and P.D. Killen. 1993. Altered aldose reductase gene regulation in cultured human retinal pigment epithelial cells. J. Clin. Invest. 92:617-623.

29. Church, G.M., and W. Gilbert. 1984. Genomic sequencing. Proc. Natl. Acad. Sci. USA. 81:1991-1995.

30. Cleveland, D.W., M.A. Lopata, R.I. McDonald, N.J. Cowan, W.J. Rutter, and M.W. Kirschner. 1980. Number and evolutionary conservation of alpha- and beta-tubulin and cytoplasmic beta- and gamma-actin genes using specific cloned cDNA probes. Cell. 264:16905-16909.

31. Kador, P.F., J.H. Kinoshita, W.H. Tung, and L.T. Chylack, Jr. 1980. Differences in the susceptibility of various aldose reductases to inhibition. II. Invest. Ophthalmol. \& Visual Sci. 19:980-982.

32. Hootman, S.R., J.E. Jones, R. Kapoor, K.-L. Nguyen, and J. de Ondarza. 1996. Na,K-ATPase constitutes a primary site of dysfunction in the pancreatic duct system in insulin-dependent diabetes mellitus. Pancreas. 13:439.

33. Uchida, S., A. Garcia-Perez, H. Murphy, and M. Burg. 1989. Signal for induction of aldose reductase in renal medullary cells by high external $\mathrm{NaCl}$. Am. J. Physiol. 256:C614-C620.

34. Sands, J.M., Y. Terada, L.M. Bernard, and M.A. Knepper. 1989. Aldose reductase activities in microdissected rat renal tubule segments. Am. J. Physiol. 256:F563-F569.

35. Burg, M.B. 1994. Molecular basis for osmoregulation of organic osmolytes in renal medullary cells. J. Exp. Zool. 268:171-175.

36. Martial, S., S.R. Price, and J.M. Sands. 1995. Regulation of aldose reductase, sorbitol dehydrogenase, and taurine cotransporter mRNA in rat medulla. J. Am. Soc. Nephrol. 5:1971-1978.

37. Dorin, R.I., V.O. Shah, D.L. Kaplan, B.S. Vela, and P.G. Zager. 1995. Regulation of aldose reductase gene expression in renal cortex and medulla of rats. Diabetologia. 38:46-54.

38. Ferraris, J.D., C.K. Williams, K.Y. Jung, J.J. Bedford, M.B. Burg, and A. Garcia-Perez. 1996. ORE, a eukaryotic minimal essential osmotic response element. The aldose reductase gene in hyperosmotic stress. J. Biol. Chem. 271: 18318-18321.

39. Greene, D.A., S.A. Lattimer, and A.F. Sima. 1987. Sorbitol, phospho- 
inositides, and sodium-potassium-ATPase in the pathogenesis of diabetic complications. N. Engl. J. Med. 316:599-606.

40. Haneda, M., R. Kikkawa, T. Arimura, K. Ebata, M. Togawa, S. Maeda, T. Sawada, N. Horide, and Y. Shigeta. 1990. Glucose inhibits myo-inositol uptake and reduces myo-inositol content in cultured rat glomerular mesangial cells. Metab. Clin. Exp. 39:40-45.

41. Nishizuka, Y. 1989. The family of protein kinase C for signal transduction. J. Am. Med. Assoc. 262:1826-1833.

42. Tilton, R.G., L.D. Baier, J.E. Harlow, S.R. Smith, E. Ostrow, and J.R. Williamson. 1992. Diabetes-induced glomerular dysfunction: links to a more reduced cytosolic ratio of NADH/NAD ${ }^{+}$. Kidney Int. 41:778-788.

43. Wolf, B.A., J.R. Williamson, R.A. Easom, K. Chang, W.R. Sherman, and J. Turk. 1991. Diacylglycerol accumulation and microvascular abnormalities induced by elevated glucose levels. J. Clin. Invest. 87:31-38.

44. Ishii, H., M.R. Jirousek, D. Koya, C. Takagi, P. Xia, A. Clermont, S.-E. Bursell, T.S. Kern, L.M. Ballas, W.F. Heath, et al. 1996. Amelioration of vascular dysfunctions in diabetic rats by an oral PKC inhibitor. Science (Wash. DC). 272:728-731.

45. Hermenegildo, C., V. Felipo, M.-D. Minana, F.J. Romero, and S. Grisolia. 1993. Sustained recovery of $\mathrm{Na}^{+}-\mathrm{K}^{+}$- ATPase activity in sciatic nerve of dia- betic mice by administration of $\mathrm{H} 7$ or calphostin $\mathrm{C}$, inhibitors of PKC. Diabetes. 42:257-262.

46. Lowndes, J.M., M. Hokin-Neverson, and P.J. Bertics. 1990. Kinetics of phosphorylation of Na/K-ATPase by protein kinase C. Biochim. Biophys. Acta. 1052:143-151.

47. Bertorello, A.M., A. Aperia, S.I. Walaas, A.C. Nairn, and P. Greengard 1991. Phosphorylation of the catalytic subunit of $\mathrm{Na}^{+}, \mathrm{K}^{+}$-ATPase inhibits the activity of the enzyme. Proc. Natl. Acad. Sci. USA. 88:11359-11362.

48. Middleton, J.P., W.A. Khan, G. Collinsworth, Y.A. Hannun, and R.M. Medford. 1993. Heterogeneity of protein kinase C-mediated rapid regulation of Na/K-ATPase in kidney epithelial cells. J. Biol. Chem. 268:15958-15964.

49. Borghini, I., K. Geering, A. Gjinovci, C.B. Wolheim, and W.F. Pralong 1994. In vivo phosphorylation of the $\mathrm{Na}, \mathrm{K}-\mathrm{ATPase}$ alpha subunit in sciatic nerves of control and diabetic rats: effects of protein kinase modulators. Proc. Natl. Acad. Sci. USA. 91:6211-6215.

50. Xia, P., R.M. Kramer, and G.L. King. 1995. Identification of the mechanism for the inhibition of $\mathrm{Na}^{+}, \mathrm{K}^{+}$-adenosine triphosphatase by hyperglycemia involving activation of protein kinase $\mathrm{C}$ and cytosolic phospholipase $\mathrm{A}_{2}$. J. Clin. Invest. 96:733-740. 